Marta Sienkiewicz ${ }^{1}$

Adam Mickiewicz University, Poznan, Poland

Faculty of Theology

Wojciech Świder ${ }^{2}$

Poznan University of Economics and Business, Poznan, Poland

Department of Public Finance

\title{
The Overview of the Economic System in Papal Encyclicals
}

\section{Introduction}

The article presents how popes responded in their documents, especially encyclicals, to the emerging changes in the political system and new economic ideas. References were given to individual fragments dealing with issues related to economics, especially in the field of freedom, work, property and entrepreneurship. This method of analysis allows to present the position of the popes regarding specific economic systems.

The first aim of the article is to analyze the postulated socio-economic system in selected papal encyclicals and to show their role in shaping the socio-economic system in the western civilization circle.

The second goal is to show the dynamics of the postulated socio-economic system in papal encyclicals. Two hypotheses have been put forward, the first one is to determine whether the content of the encyclicals is closely related to the negative aspects of economic reality, and the second is to show that the economic

${ }^{1}$ Marta Sienkiewicz - PhD student at the Faculty of Theology at Adam Mickiewicz University in Poznan; teacher of religion and art. Research interests: missiology, biology, art, e-mail: marta.sienkiewicz@amu.edu.pl. ORCID:0000-0001-5258-4675.

2 Wojciech Świder - PhD, researcher and lecturer at Poznan University of Economics and Business. Research interests: monetary policy, fiscal policy, financial markets, behavioral economics, e-mail: wojciech.swider@ue.poznan.pl. ORCID: 0000-0002-0791-5460. 
system postulated in the encyclicals has changed over time in response to current social conditions.

The next part of the text presents the economic conditions of individual stages of socio-economic life and the reaction of the popes to them expressed in the text of the encyclicals.

\section{Industrialization and its dark side}

Industrialization in Great Britain took place relatively quickly compared to the rest of the world. During the first census (1801) it was documented that $1 / 3$ of the population worked in agriculture ${ }^{3}$. In 1851 , this share was slightly more than $1 / 5^{4}$. The migration of people to cities caused the deterioration of living conditions (population density, tragic living conditions, polluted air, spreading diseases) ${ }^{5}$. Social bonds have been severed, and modern city dwellers saw them as "the

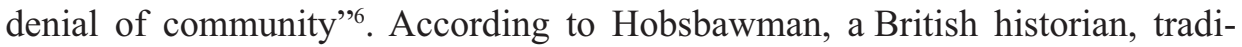
tional values, morality and folk wisdom, which grew out of agrarian culture, were inadequate to living in a capitalist economy ${ }^{7}$. Marx and Engels argued that; during the industrial revolution we had to deal with two phenomena: the expropriation of the workpiece from the product (the worker no longer owned the tools he worked with, did not dispose of the final product) and the expropriation of nature, which manifested itself in alienation and loss of control over the work process. In the 1830 s, workers demanded a shorter working day and a division into working and non-working days ${ }^{8}$. Working conditions in cities were disastrous at the time, significantly reducing life expectancy ${ }^{9}$.

In the Victorian Era, there was a demand for child labor during the Industrial Revolution, which was not a new phenomenon. Children in poor families worked in the land as early as their parents could find employment for them, but

${ }^{3}$ Before 1801, many people combined farming with employment in industry or working in a mine. J.G. Rule, The Experience of Labour in Eighteenth-Century Industry, London \& Sydney 1981.

${ }^{4}$ By 1700 , half of the population was employed in agriculture.

5 The difference between the mortality of the urban and rural population decreased in the 18 th century, while in the 19th century it was possible to observe increasing differences again.

6 J.G. Rule, Labour in a changing economy 1700-1850, https://www.ehs.org.uk/dotAsset/ a9ce710d-3b24-406c-9652-07bf43657f86.pdf [accessed 19.10.2020].

${ }^{7}$ E.J. Hobsbawm, Industry and Empire: From 1750 to the Present Day, London 1968.

${ }^{8}$ Such a division had already existed in the 18 th century before the appearance of the factory system. J.G. Rule, Labour in a changing economy, 1700-1850.

${ }^{9}$ According to the report by Edwin Chadwick (1844), the statistical average life expectancy could be: in Manchester 17 years, Leeds 19 years, in Truro 28 years, in the villages of Rutland 38 years. E. Chadwick, Report on the Sanitary Condition of the Labouring Population of Great Britain: A Supplementary Report on the Results of a Special Inquiry into the Practice of Interment in Towns, "Br Foreign Med Rev." vol. 17 (1844) 34. 
the industrial revolution created the conditions for child labor in simple, repetitive activities. In 19th century Britain, on average, children started working at the age of $10^{10}$. Edwards ${ }^{11}$, who worked on a farm in the mid-1800s, recalls that his overseer never missed an opportunity to beat him. The author points out that this behavior was no exception, pointing to the fact that all poor boys were mistreated at the time. Langdon ${ }^{12}$ described how he was nearly killed by a drunk farm worker, but his parents decided not to change employers because at the time there was no such choice and the economic situation prevented them from supporting their child without using his work. Violence against defenseless workers turned out to be a more difficult social problem than excluding the youngest children from working in factories ${ }^{13}$. Friedrich Engels described 19th century Manchester as dirt, ruin and uninhabitableness, it was just hell on earth ${ }^{14}$.

The papal response to the difficult conditions of workers created by the industrial revolution was formulated in the encyclical of Leo XIII Rerum Novarum. The document was also a response to the growing popularity of communist ideas, which were ungodly in nature. The encyclical recognizes the problem of amassing great riches in the hands of a few while impoverishing the masses. The reason for this was the progress in industry and new production methods. Leo XIII also notes that the communion between workers and the increase in self-confidence, combined with the deterioration of morals, led to social antagonisms ${ }^{15}$.

The encyclical notices intensifying competition between entrepreneurs, which has led to workers being put at a disadvantage: "and so the lonely and defenseless workers saw themselves, in time, betrayed by the inhumanity of their masters and the unbridled greed of their competitors" (RN 2).

Usury and the oligopolisation of the labor market have been criticized (RN 2), the Pope unequivocally rejects socialism as a false solution, opting for private property, providing economic arguments and referring to human natural rights (RN 3).

The encyclical text defines the desired attitudes of employees (faithful and reliable performance of work, fulfillment of obligations specified in the contract, adequate behavior towards the employer) (RN 16). The Pope also exhorts employers to respect the dignity of employees, take into account their religious

${ }^{10}$ E. Griffin, Child labour, https://www.bl.uk/romantics-and-victorians/articles/child-labour [accessed 26.10.2020].

${ }^{11}$ G. Edwards, From Crow-Scaring to Westminster: an Autobiography with a foreword by the Rt. Hon. Lord Ailwyn of Honingham, introduction by W.R. Smith, London 1922, pp. 18-19.

12 R. Langdon, The Life of Roger Langdon. Told by Himself, London 1909, pp. 31-33.

13 Ibidem.

${ }^{14}$ F. Engels, The Condition of the Working-Class in England in 1844, London 1892, p 53.

${ }_{15} \mathrm{RN}$ : Leon XIII, Rerum novarum, http://www.mop.pl/doc/html/encykliki/Rerum\%20novarum. htm [accessed 26.10.2020]. 
needs, and not expose employees to corruption and temptation to $\sin (\mathrm{RN} 16)$. The working conditions which distract the employee from his family life and saving habits were also criticized (RN 16). The author of the encyclical obligated employers to adapt work to the gender and age of the worker, paying particular attention to establishing an adequate wage (RN 17).

The Pope criticizes what today is called the employer's higher bargaining power and information asymmetry (RN 17). The last negative instrument of impoverishing the proletariat is usury, which today is of less importance in terms of interest rates as in many countries interest rates have been significantly lowered over the last decade, but on the other hand, the entire monetary system is based on debt. Money is created by creating debt.

Leo XIII in his text suggests that the weakest citizens of the state should be provided with economic protection, which would be manifested in providing them with sufficient livelihoods. The Pope also adds that exercising such care will not negatively affect anyone, but will contribute to focusing on those who work to produce goods for the whole of society (RN 26).

The encyclical contains a clear suggestion to regulate the labor market and provide employees with appropriate benefits, e.g. leaves for regeneration (RN 32). As one of the overarching goals that the state should set itself, the Pope calls for the exclusion of the exploitation of workers for profit. He emphasizes that it is important to pay attention to the appropriate management of working time, in accordance with human possibilities resulting from nature. Bishop of Rome at the time clearly rejects the classical view (classical in terms of classical economics) that wages are mechanically determined in the market by supply and demand ( $R N$ 33). A fair wage is a prerequisite for a fair distribution of goods, which, according to Leo XIII, is a factor that promotes social stability. It was also important for the Pope to draw attention to the awakening of a kind of hope in employees, which will motivate them to work and make them realize that by their own honest actions the employee will be able to achieve what he needs. (RN 35).

\section{The Great Depression of 1929 and the Great Recession}

The Great Depression of 1929 had severe consequences ${ }^{16}$, both in macroeconomic terms and in terms of individuals (companies and households). From 1929

16 The crisis of 1929 spread to many countries in Europe. Germany, burdened with reparations from World War I, was particularly hard hit by it. Social tensions over mass unemployment paved the way for the Nazis to power along with the ideas of Nazism, fascism and militarism that led to the outbreak of World War II. 
to 1933 , the real GDP of developed countries contracted by about $16 \%$, while prices fell by almost $30 \%$ (deflation) ${ }^{17}$.

The cause of the deep and difficult to amortize crisis was the gold standard, which makes it impossible to conduct an expansive monetary and fiscal policy, and largely excludes the possibility of currency depreciation in order to improve the competitiveness of exports ${ }^{18}$ (under the gold standard, you can reduce the coverage of the currency in the bullion, but such a procedure has a negative effect for its credibility).

Under The American Restoration and Recovery Act, approximately USD 800 billion has been allocated to stimulating the economy. Christina Romer (2009) described these actions as the "biggest and boldest countercyclical action in American History"19.

Cooling down the economy was deliberate. The Federal Reserve, after many years of monetary expansion, raised interest rates from $3.5 \%$ to $5 \%$ and sold Treasury bonds. On the other hand, the monetary authorities, perhaps, did not expect such a drastic slowdown ${ }^{20}$. There was a wave of bankruptcies that was favored by the deflationary environment, which Irving Fisher (1933) wrote about among others. In March 1933, the vast majority of the banks were closed for fear of some collapse ${ }^{21}$.

During the Great Depression, the US managed to maintain a trade surplus, but other advanced economies experienced a decline in demand, which also hit US exports ${ }^{22}$. Herbert Hoover had a high tariff policy. The priority was to protect against competition from domestic companies that create high-quality jobs ${ }^{23}$.

The gold standard was deviated from during the Great Depression. In 1931, 47 countries were members of the "gold-standard club". At the end of 1932, the only important members of this association were: Belgium, France, the

17 N. Crafts, P. Fearon, Lessons from the 1930s Great Depression, "Oxford Review of Economic Policy" vol. 26 (2010) 3, pp. 285-317.

${ }^{18}$ B. Eichengreen, P. Temin, Fetters of Gold and Paper, "Oxford Review of Economic Policy" vol. 26 (2010) 3, pp. 370-384.

19 C. Romer, The Economic Crisis: Causes, Policies and Outlook. Testimony before the Joint Economic Committee (2009), https://obamawhitehouse.archives.gov/administration/eop/cea/JECTestimony-04302009 [accessed 30.09.2021].

${ }^{20}$ N. Crafts, P. Fearon, Lessons from the 1930s Great Depression, pp. 285-317.

${ }^{21}$ C.W. Calomiris, The Political Lessons of Depression-era Banking Reform, "Oxford Review of Economic Policy" vol. 26 (2010) 3, pp. 540-560.

${ }_{22}$ D.A. Irwin, M.D. Bordo, C. Goldin, E.N. White, From Smoot-Hawley to Reciprocal Trade Agreements: Changing the Course of US Trade Policy in the 1930s, The Defining Moment. The Great Depression and the American Economy in the Twentieth Century, Chicago 1998, pp. 325-352.

${ }^{23}$ R.K. Vedder, L.E. Gallaway, Out of Work: Unemployment and Government in Twentiethcentury America, New York 1993. 
Netherlands, Poland, Switzerland and the USA ${ }^{24}$. In 1935, it became clear that the countries that abandoned the gold system were much better off and did not experience hyperinflation as feared ${ }^{25}$. The Labor Relations Act (1935) contained provisions promoting trade unions and workers' rights ${ }^{26}$.

A consequence of the Great Depression was the growing role of social transfers. Among the OECD countries, in the 50 years from 1930 to 1980, the share of these transfers increased in median terms from 1.6 to $20.09 \%$ of GDP ${ }^{27}$.

During the Great Depression, the encyclical Quadragesimo anno ${ }^{28}$ was published, authored by Pius XI. The text refers to the protection of workers by the state, postulated by Leo XIII, at the expense of wealthy social strata. In Quadragesimo anno there is also an expression of support for Christian workers' organizations, at the same time there is regret for the greater popularity of socialist and communist organizations (QA 36). Pius XI regrets that the insufficient number of employers grouped into the organizations postulated by Leo XIII (QA 38). There is clear support for private property in the encyclical (QA 49). Following Leo XIII, Pius XI emphasizes that in the production of goods both capital and human labor are inextricably needed (QA 53). He notes the progress in the area of workers' standard of living, but he also notes the concentration of ownership in the most economically developed countries (QA 59). It is worth remembering that these remarks were made before the New Deal program initiated by F.D. Roosevelt that drastically increased the scale of consumer demand support, which was manifested by the introduction of unemployment benefits or retirement benefits ${ }^{29}$.

Pius XI indicates the need of accumulating savings in the hands of workers, but points to the fact that such a state of affairs should not have a negative impact on the willingness to work (QA 61). An important postulate in the encyclical is to encourage employees to participate in the ownership of the company in which they work, there is a mention of a partnership agreement, which, as a result, may turn out to be beneficial for employees and employers (QA 65). The negative

${ }^{24}$ B. Eichengreen, Golden Fetters: The Gold Standard and the Great Depression 1919-1939, New York 1992.

${ }^{25}$ N. Crafts, P. Fearon, Lessons from the 1930s Great Depression, pp. 285-317.

${ }^{26}$ Ibidem.

27 P.H. Lindert, Growing Public, Cambridge 2004.

${ }^{28}$ This encyclical is considered crucial for the development of the theory of the social market economy, specifically with a view to the deproletarisation of the masses. QA: Pius XI, Quadragesimo anno, https://www.vatican.va/content/pius-xi/en/encyclicals/documents/hf_p-xi_enc_19310 515_quadragesimo-anno.html [accessed 12.07.2021].

${ }^{29}$ The increase in social transfers has generally occurred in developed countries, as already mentioned in this text. P.H. Lindert, Growing Public. Such activities had a theoretical background in Keynesianism. J.M. Keynes, The general theory of employment, interest and money, New York 1936. 
effects of free competition, which is a necessary condition for the functioning of the market in the classical sense (see A. Smith), are attributed by Pius XI to individualism (QA 105).

\section{The fall of the gold standard and inflation in the 1970s}

The 1970s were marked by a departure from the gold standard in 1971, followed by the rising inflation that resulted from the 1973 Yom Kippur War. The ArabIsraeli dispute and the US seizure of Israel led to the introduction of an embargo on oil from Arab countries, which caused cost inflation in Western countries, especially in the US. Rising prices were the reason for pursuing a hawkish monetary policy manifested in high interest rates. This meant a drastic deterioration of the credit conditions of developing countries (e.g. in Latin America), due to the large share of debt in the US dollar.

The social encyclical of Pope John Paul II, Laborem exercens ${ }^{30}$, published on September 14, 1981, dealt with the issue of human work. In the years preceding dynamic liberalism and globalization, John Paul II already noticed the occurrence of global phenomena and growing social inequalities (LE 2). He positively relates to technical progress, which is understood as a set of tools conducive to man in the work he undertakes, but he also draws attention to the dangers of the automation and mechanization of human work, which should not be ignored (LE 5).

The encyclical recognizes work as an element of own initiative and it opposes excessive bureaucracy (LE 15). In the document, John Paul II encourages women to work for gainful employment, as long as it does not contradict the possibility of starting a family, signals support for employees' health insurance (LE 19) and points out that employees have the right to strike for a good cause, although this right should not be abused (LE 20).

\section{Reaganomics and Thatcherism: neoliberalism of the 1980s}

The 1980s was largely dominated by Thatcherism as the political and economic current that formed in response to the crisis of the 1970s, characterized by high unemployment and high inflation ${ }^{31}$ (rising prices were the result of oil shocks). Margaret Thatcher's policy is characterized as neoliberal, emphasizing

${ }^{30}$ LE: John Paul II, Laborem exercens, https://www.vatican.va/content/john-paul-ii/pl/ency clicals/documents/hf_jp-ii_enc_14091981_laborem-exercens.html [accessed 14.07.2021].

${ }^{31}$ C. Hay, Whatever Happened to Thatcherism?, "Political Studies Review" vol. 5 (2007) 2, pp. 183-201. 
the market, a small role of the state in the economy, and smaller social benefits. Under the rule of the "Iron Lady", the City of London was strengthened, including the British financiers ${ }^{32}$. One can even speak of hyper-financialisation. During Thatcher's rule, privatization was intensified and as well as trade union protests. One could also observe the trend of state centralization - the central government had more power at the expense of local authorities ${ }^{33}$.

According to Tarshis ${ }^{34}$, Roland Reagan clearly transformed the fabric of the US economy. The Republican took power after the oil crises when the US was reigning with high inflation, negative business sentiment, and high taxes. In replacing Carter, he promised to make "America proud again". According to Reagan, the government was responsible for the failure of the economy. Reagan's program was simple: cutting taxes, increasing defense spending, and balancing the federal budget. In order to implement his postulates, he undertook a series of actions that were to cause wealth to "drip down". Stock markets crashed in 1987 and the downward flow theory proved wrong. The public debt increased by Reagan was a burden on the US budget, the cost of servicing the debt in 1986 was $\$ 136$ billion, in 1980 it accounted for $8.7 \%$ of federal government spending, to increase to $16.5 \%$ in $1986^{35}$.

In the early 1990s, John Paul II published the encyclical Centesimus annus ${ }^{36}$. It can be interpreted in the context of growing neoliberalism under the Thatcher rule and the Reagan presidency. John Paul II fits in with the idea initiated by Leo XIII, criticizing the perception of work as a commodity, without taking into account the minimum subsistence of an employee. The document also emphasizes the importance of social assistance. The Pope expressed the need to improve the skills of employees (CA 15), pointed to the benefits of using various techniques to increase work efficiency, thanks to which it will be possible to raise the standard of living of citizens.

There is also a strong condemnation of consumerism in the encyclical text (CA 19). In the context of these considerations, the emphasis on creativity and entrepreneurship by John Paul II (CA 32) is new ${ }^{37}$.

${ }^{32}$ B. Jessop, Margaret Thatcher and Thatcherism: Dead but not buried, "British Politics, Special Issue" vol. 10 (2015) 1, pp. 16-30.

${ }^{33}$ Ibidem.

${ }^{34}$ L. Tarshis, The legacy of Reaganomics. (Ronald Reagan's policies), "Scholastic Update" vol. 124 (1992), p. 10.

35 C.P. Wallace, The Macroeconomic Legacy of Reaganomics, "Journal of economic issues" vol. 22 (1988) 1, pp. 1-16.

${ }^{36}$ [CA:] John Paul II, Centesimus annus, https://www.vatican.va/content/john-paul-ii/p1/ encyclicals/documents/hf_jp-ii_enc_01051991_centesimus-annus.html [accessed 17.07.2021].

${ }^{37}$ In this passage, the Pope refers to his encyclical Sollicitudo rei socialis of 1987. 
The Polish Pope made it clear that he was in favor of removing barriers to trade and monopolies. This is a sign of recognition of the path of development through exports, which China has chosen after Deng Xaoping's reforms ${ }^{38}$, and he also raised the issue of foreign debt (CA 35).

Already in the encyclical of 1991, attention is drawn to the issue of environmental pollution (CA 37). The Pope points out that people, instead of fulfilling the role of God's collaborators in taking care of the world created by him, want to take his place themselves, which leads to disorder (CA 37). John Paul II points out that the state should ensure a stable ownership situation so that productive labor and the use of its fruits would be possible. The encyclical condemns the welfare state and bureaucracy (CA 48).

\section{The financial crisis of 2008-2009}

The 2008-2009 crisis had several causes. The main ones include: excessive leveraging of transactions on the financial market ${ }^{39}$, securitization of financial assets, i.e. changing their form, e.g., from bank assets to financial instruments that can be sold on the market ${ }^{40}$, shadow banking, i.e. the financial system beyond state regulation ${ }^{41}$, incorrect risk assessments of credit agencies ${ }^{42}$ or insider trading, i.e. making transactions based on information not available to the public ${ }^{43}$. The economic downturn took place both in the USA and in many developed and developing countries. A similar "contagion" mechanism took place during the Great

${ }^{38}$ S.L. Shirk, Playing to the Provinces: Deng Xiaoping's Political Strategy of Economic Reform, "Studies in Comparative Communism" vol. 23 (1990) 3-4, pp. 227-258. B. Naughton, Deng Xiaoping: The Economist, "The China Quarterly" 135 (1993), pp. 491-514.

${ }^{39}$ R. Glick, K.J. Lansing, Global household leverage, house prices, and consumption, "FRBSF Economic Letter" vol. 1 (2010), pp. 1-5, http://homepage.ntu.edu.tw/ nankuang/Glo bal $\% 20$ Household $\% 20$ Leverage, $\% 20$ House $\% 20$ Prices, $\% 20$ and $\% 20$ Consumption-1.pdf [accessed 23.07.2021].

${ }^{40}$ A.T. Hossain, L. Kryzanowski, Global financial crisis after ten years: a review of the causes and regulatory reactions, "Managerial Finance" vol. 45 (2019) 7, pp. 904-924.

${ }^{41}$ Y. Nersisyan, L.R. Wray, The Global Financial Crisis and the Shift to Shadow Banking, New York, Levy Economics Institute Working Paper, https://papers.ssrn.com/sol3/papers. cfm?abstract_id=1559383 [accessed 26.10.2020]. M. Ricks, Shadow banking and financial regulation, Slides, http://citeseerx.ist.psu.edu/viewdoc/download? doi=10.1.1.394.4231\&rep=rep1 \&type $=$ pdf [accessed 12.07.2021]. V.V. Acharya, P. Schnabl, G. Suarez, Securitization without risk transfer, "Journal of Financial Economics" vol. 107 (2013) 3, pp. 515-536.

42 J.M. Griffin, D.Y. Tang, Did credit rating agencies make unbiased assumptions on CDOs?, “American Economic Review” vol. 101 (2011) 3, pp. 125-130.

${ }^{43}$ P. Cziraki, Trading by bank insiders before and during the 2007-2008 financial crisis, “Journal of Financial Intermediation” vol. 33 (2018), pp. 58-82. 
Depression that began in 1929. In response to the crisis, the debate has intensified and the need to strictly regulate the financial sector ${ }^{44}$, which seems to be detached from the real economy and focused only on short-term profit.

In this context, Pope Francis refers to economic issues in his encyclical Fratelli tutti. Criticism of the existing organization of the world economy emerges from the content of the encyclical of the Holy Father Francis Fratelli tutt ${ }^{45}$. The neoliberal profit-maximization paradigm has been very clearly criticized. It is expressed in the passage, "There are many forms of injustice in the world today, reinforced by narrow anthropological visions and by the profit-based economic model (...)" (FT 22). Later in the document, the Pope also touched upon this issue (FT 168). The financial crisis of 2007-2008, according to Pope Francis, was an opportunity to reform the economic system. The Pope also suggests that if he had not been adequately responded to, that would have led to reflection and change (FT $170)^{46}$. The instrumental use of globalization to meet the financial goals of global powers (FT 12) and the accumulation of power by them at the expense of nation states has been criticized. The Pope states that in the 21 st century, the weakening of the power of nation states can be observed, primarily because the economic and financial dimension of a supranational nature tends to dominate politics (FT 172). Pope Francis draws attention to the problem of replacing some human labor by machines (FT 33) and calls for active state policy to promote an economy conducive to production diversity and creative entrepreneurship ${ }^{47}$, which is to help increase, not reduce the number of jobs (FT 168). The encyclical raises the issue of care for the natural environment (FT 17), which is also a very live topic among economists. More specifically, we are talking about the so-called external effects, i.e. losses (pollution et cetera) generated by an enterprise in the natural environment or the local community ${ }^{48}$.

${ }^{44}$ A.T. Hossain, L. Kryzanowski, Global financial crisis after ten years: a review of the causes and regulatory reactions, pp. 904-924.

45 [FT:] Francis, Fratelli tutti, https://www.vatican.va/content/francesco/pl/encyclicals/docu ments/papa-francesco_20201003_enciclica-fratelli-tutti.html [accessed 23.07.2021].

${ }^{46}$ In addressing this issue, Pope Francis also refers to the previously written encyclical Laudato si'.

${ }^{47}$ Francis, Laudato si', https://www.vatican.va/content/francesco/pl/encyclicals/documents/ papa-francesco_20150524_enciclica-laudato-si.html, 129 [accessed 23.07.2020].

48 J.F. Henri, M. Journeault, Eco-control: the influence of management control systems on environmental and economic performance, "Accounting, Organizations and Society" vol. 35 (2010) 1, pp. 63-80. J. Unerman, J. Bebbington, B. O'dwyer, Corporate reporting and accounting for externalities, “Accounting and Business Research" vol. 48 (2018) 5, pp. 497-522. 


\section{Conclusions}

In conclusion, it can be said that the popes are not in favor of any particular regime. They only indicate the desired activities of decision-makers, while criticizing aspects of the existing reality (e.g. collectivism in the communist sense and individualism in the neoliberal sense). These postulates suggest a system called social market economy ${ }^{49}$. Free market mechanisms, in this context, are subject to social control (CA 19). Popes show what elements of management are consistent with the content of the Holy Scriptures, being witnesses of the times in which specific economic and social systems were created and developed. There is no information in the Scriptures about the most desirable system, but there are several threads that relate to the economic sphere.

The first goal of the paper was to analyze the postulated socio-economic system in selected papal encyclicals and to show their role in shaping the socio-economic system in the western civilization circle. The text presents such a review and indicates their significant role in shaping the socio-economic reality, including by taking a firm stand against communism and "civilizing" labor relations at the end of the 19th century (Rerum novarum). The direct fruit of the popes' thought was the system known as the social market economy.

The second goal was to show the dynamics of the postulated socio-economic system in papal encyclicals, which was formulated in the first hypothesis, according to which the content of the encyclicals is closely related to the negative aspects of the economic reality at that time. This is evident in the study, although the link differs depending on the encyclical itself. An attempt to assess the relationship between the content of a given encyclical and the negative aspects of economic reality at that time is as follows: in the encyclical Rerum novarum it is very clear, in Quadragesimo anno it is weak, in Laborem exercens it is moderate, and in Centesimus annus and Fratelli tutti it is considerable.

According to the second hypothesis, the economic system postulated in encyclicals has changed over time in response to current social conditions. This hypothesis cannot be unequivocally accepted or rejected. The papal encyclicals did not postulate one specific economic system, but only indicated undesirable phenomena and postulated a certain state of affairs. It can be concluded that the fundamental principles of the organization of socio-economic life have remained unchanged, as well as respect for private property, human dignity and work, and adequate payment for this work. Both the communist (common factors of production) and liberal attitudes were criticized, followed by the neoliberal idea

49 Pursuant to Art. 20 of the Constitution of the Republic of Poland. "A social market economy based on the freedom of economic activity, private property and solidarity, dialogue and cooperation of social partners is the basis of the economic system of the Republic of Poland". 
of work as one of the many factors of production, the cost of which should be reduced as much as possible, in order to maximize the company's profit. On the other hand, the analyzed period covered over 100 years, so the social conditions changed. For example, in the encyclicals Centesimus annus and Fratelli tutti, the issues of care for the natural environment appear, which did not raise much interest in the industrial era.

\section{Summary}

The article is an analysis and presentation of the overview of economic systems to which the popes of that time referred in their documents, most often in encyclicals. The article presents the image of society in the economic and social perspective as well as interpretations and comments on a specific system, which were included in the papal encyclicals. The article is a presentation of how popes in encyclicals responded to the emerging changes in the political system and new economic ideas.

\section{Keywords}

economic system, social market economy, Catholic social teaching, Rerum novarum

\section{Obraz ustroju gospodarczego w wybranych encyklikach papieskich}

\section{Streszczenie}

Artykuł jest analizą i zobrazowaniem ustrojów gospodarczych, do których odwoływali się ówcześni papieże w swoich dokumentach, najczęściej w encyklikach. W artykule został przedstawiony obraz społeczeństwa w perspektywie gospodarczo-społecznej oraz zawarte w encyklikach interpretacje i komentarze do konkretnego ustroju. Artykuł prezentuje to, w jaki sposób papieże reagowali w encyklikach na pojawiające się zmiany w ustroju politycznym i na nowe idee gospodarcze.

\section{Słowa kluczowe}

ustrój gospodarczy, społeczna gospodarka rynkowa, katolicka nauka społeczna, Rerum novarum

\section{Bibliography}

Acharya V.V., Schnabl P., Suarez G., Securitization without risk transfer, "Journal of Financial Economics" vol. 107 (2013) 3, pp. 515-536.

Arslanalp S., Henry P.B., Policy Watch: Debt Relief, "Journal of Economic Perspectives" vol. 20 (2006) 1, pp. 207-220. 
Busby J.W., Bono Made Jesse Helms Cry: Jubilee 2000, Debt Relief, and Moral Action in International Politics, "International Studies Quarterly" vol. 51 (2007) 2, pp. 247 -275 .

Calomiris C.W., The Political Lessons of Depression-era Banking Reform, "Oxford Review of Economic Policy" vol. 26 (2010) 3, pp. 540-560.

Chadwick E., Report on the Sanitary Condition of the Labouring Population of Great Britain: A Supplementary Report on the Results of a Special Inquiry into the Practice of Interment in Towns, "Br Foreign Med Rev." vol. 17 (1844) 34, pp. 403-407.

Chesnais F., Bezprawne dtugi - jak banki sterują demokracja, Warszawa 2012.

Crafts N., Fearon P., Lessons from the 1930s Great Depression, "Oxford Review of Economic Policy" vol. 26 (2010) 3, pp. 285-317.

Cziraki P. Trading by bank insiders before and during the 2007-2008 financial crisis, "Journal of Financial Intermediation" vol. 33 (2018), pp. 58-82.

Easterly W., Debt Relief, "Foreign Policy” 127 (2001), pp. 20-26.

Edwards G., From Crow-Scaring to Westminster: an Autobiography with a foreword by the Rt. Hon. Lord Ailwyn of Honingham, introduction by W.R. Smith, London 1922, pp. 18-19.

Eichengreen B., Temin P., Fetters of Gold and Paper, "Oxford Review of Economic Policy" vol. 26 (2010) 3, pp. 370-384.

Eichengreen B., Golden Fetters: The Gold Standard and the Great Depression 1919-1939, New York 1992.

Engels F., The Condition of the Working-Class in England in 1844, London 1892.

Fisher I., The Debt-Deflation Theory of Great Depressions: Introductory, "Econometrica" vol. 1 (1933), pp. 337-357.

Francis, Fratelli tutti, https://www.vatican.va/content/francesco/pl/encyclicals/documents/papa-francesco_20201003_enciclica-fratelli-tutti.html [accessed 23.07.2021].

Francis, Laudato si', https://www.vatican.va/content/francesco/pl/encyclicals/documents/ papa-francesco_20150524_enciclica-laudato-si.html, 129 [accessed 23.07.2020].

Glick R., Lansing K.J., Global household leverage, house prices, and consumption, "FRBSF Economic Letter" vol. 1 (2010), pp. 1-5, http://homepage.ntu.edu.tw/ nankuang/ Global\%20Household\%20Leverage, $\% 20$ House \%20Prices, $\% 20$ and $\% 20$ Consumption- 1 . pdf [accessed 23.07.2021].

Griffin E., Child labour, https://www.bl.uk/romantics-and-victorians/articles/childlabour [accessed 26.10.2020].

Griffin J.M., Tang D.Y., Did credit rating agencies make unbiased assumptions on CDOs?, “American Economic Review” vol. 101 (2011) 3, pp. 125-130.

Hay C., Whatever Happened to Thatcherism?, "Political Studies Review" vol. 5 (2007) 2, pp. 183-201.

Henri J.F., Journeault M., Eco-control: the influence of management control systems on environmental and economic performance, "Accounting, Organizations and Society" vol. 35 (2010) 1, pp. 63-80. 
Hobsbawm E.J., Industry and Empire: From 1750 to the Present Day, London 1968.

Hossain A.T., Kryzanowski L., Global financial crisis after ten years: a review of the causes and regulatory reactions, "Managerial Finance" vol. 45 (2019) 7, pp. 904-924 .

Irwin D.A., Bordo M.D., Goldin C., White E.N., From Smoot-Hawley to Reciprocal Trade Agreements: Changing the Course of US Trade Policy in the 1930s, The Defining Moment. The Great Depression and the American Economy in the Twentieth Century, Chicago 1998, pp. 325-352.

John Paul II, Centesimus annus, https://www.vatican.va/content/john-paul-ii/pl/encyclicals/ documents/hf_jp-ii_enc_01051991_centesimus-annus.html [accessed 17.07.2021].

John Paul II, Laborem exercens, https://www.vatican.va/content/john-paul-ii/pl/encyclicals/ documents/hf_jp-ii_enc_14091981_laborem-exercens.html [accessed: 14.07.2021].

Jessop B., Margaret Thatcher and Thatcherism: Dead but not buried, "British Politics, Special Issue" vol. 10 (2015) 1, pp. 16-30.

Jones C., Midrigan V., Philippon T., Household leverage and the recession, "NBER Working Paper Series" no. 16965, Cambridge 2011, 2018.

Keynes J.M., The general theory of employment, interest and money, New York 1936.

Langdon R., The Life of Roger Langdon. Told by Himself, London 1909, pp. 31-33.

Leon XIII, Rerum novarum, http://www.mop.pl/doc/html/encykliki/Rerum\%20novarum. htm [accessed 26.10.2020].

Lindert P.H., Growing Public, Cambridge 2004.

Mian A., Sufi A., House prices, home equity-based borrowing, and the US household leverage crisis, “American Economic Review” vol. 101 (2011) 2, pp. 2132-2156.

Naughton B., Deng Xiaoping: The Economist, "The China Quarterly" 135 (1993), pp. 491-514.

Nersisyan Y., Wray L.R., The Global Financial Crisis and the Shift to Shadow Banking, New York, Levy Economics Institute Working Paper, https://papers.ssrn.com/sol3/ papers.cfm?abstract_id=1559383 [accessed 26.10.2020].

Pius XI, Quadragesimo anno, https:/www.vatican.va/content/pius-xi/en/encyclicals/ documents/hf_p-xi_enc_19310515_quadragesimo-anno.html [accessed 12.07.2021].

Ricks M., Shadow banking and financial regulation, Slides, http://citeseerx.ist.psu.edu/ viewdoc/download?doi=10.1.1.394.4231\&rep=rep1\&type=pdf [accessed 12.07.2021].

Romer C., The Economic Crisis: Causes, Policies and Outlook. Testimony before the Joint Economic Committee (2009), https://obamawhitehouse.archives.gov/administration/eop/cea/JEC-Testimony-04302009 [accessed 30.09.2021].

Rule J.G., Labour in a changing economy 1700-1850, https://www.ehs.org.uk/dotAsset/ a9ce710d-3b24-406c-9652-07bf43657f86.pdf [accessed 19.10.2020].

Rule J.G., The Experience of Labour in Eighteenth-Century Industry, London \& Sydney 1981.

Rule J.G., The Labouring Classes in Early Industrial England 1750-1850, Abingdon-onThames 2014. 
Shirk S.L., Playing to the Provinces: Deng Xiaoping's Political Strategy of Economic Reform, "Studies in Comparative Communism" vol. 23 (1990) 3-4, pp. 227-258.

Tarshis L., The legacy of Reaganomics. (Ronald Reagan's policies), "Scholastic Update" vol. 124 (1992), pp. 10-12.

Unerman J., Bebbington J., O'dwyer B., Corporate reporting and accounting for externalities, “Accounting and Business Research" vol. 48 (2018) 5, pp. 497-522.

Wallace C.P., The Macroeconomic Legacy of Reaganomics, "Journal of economic issues" vol. 22 (1988) 1, pp. 1-16.

Vedder R.K., Gallaway L.E., Out of Work: Unemployment and Government in Twentiethcentury America, New York 1993. 